\title{
Spatial variability in heavy metal concentration in urban pavement joints - a case study
}

\author{
Collin J. Weber, Alexander Santowski, and Peter Chifflard \\ Department of Geography, Philipps University Marburg, 35037 Marburg, Germany \\ Correspondence: Collin J. Weber (collin.weber@geo.uni-marburg.de)
}

Received: 23 June 2020 - Discussion started: 7 August 2020

Revised: 24 November 2020 - Accepted: 30 November 2020 - Published: 15 January 2021

\begin{abstract}
Heavy metals are known to be among one of the major environmental pollutants, especially in urban areas, and, as generally known, can pose environmental risks and direct risks to humans. This study deals with the spatial distribution of heavy metals in different pavement joints in the inner city area of Marburg (Hesse, Germany). Pavement joints, defined as the joint between paving stones and filled with different materials, have so far hardly been considered as anthropogenic materials and potential pollution sources in urban areas. Nevertheless, they have an important role as possible sites of infiltration for surface run-off accumulation areas and are therefore a key feature of urban water regimes. In order to investigate the spatial variability in heavy metals in pavement joints, a geospatial sampling approach was carried out on six inner city sampling sites, followed by heavy metal analyses via inductively coupled plasma-mass spectrometry (ICP-MS) and additional $\mathrm{pH}$ and organic matter analyses. A first risk assessment of heavy metal pollution from pavement joints was performed.

Pavement joints examined consist mainly of basaltic gravel, sands, organic material and anthropogenic artefacts (e.g. glass and plastics), with an average joint size of $0.89 \mathrm{~cm}$ and a vertical depth of $2-10 \mathrm{~cm}$. In general, the pavement joint material shows high organic matter loads (average $11.0 \%$ by mass) and neutral to alkaline $\mathrm{pH}$ values. Besides high $\mathrm{Al}$ and $\mathrm{Fe}$ content, the heavy metals $\mathrm{Cr}, \mathrm{Ni}, \mathrm{Cd}$ and $\mathrm{Pb}$ are mainly responsible for the contamination of pavement joints. The identified spatial pattern of maximum heavy metal loads in pavement joints could not be attributed solely to traffic emissions, as commonly reported for urban areas. Higher concentrations were detected at run-off accumulation areas (e.g. drainage gutters) and at the lowest sampling points with high drainage accumulation tendencies. Additional Spearman correlation analyses show a clear positive correlation between the run-off accumulation value and calculated exposure factor (ExF; Spearman correlation coefficients $(\mathrm{rSP})-0.80 ; p<0.00)$. Further correlation analyses revealed different accumulation and mobility tendencies of heavy metals in pavement joints. Based on sorption processes with humic substances and an overall alkaline $\mathrm{pH}$ milieu, especially $\mathrm{Cu}, \mathrm{Cd}$ and $\mathrm{Pb}$ showed a low potential mobility and strong adsorption tendency, which could lead to an accumulation and fixation of heavy metals in pavement joints. The presence of heavy metals in pavement joints poses a direct risk for urban environments and may also affect environments out of urban areas if drainage transports accumulated heavy metals. Finally, we encourage further research to give more attention to this special field of urban anthropogenic materials and potential risks for urban environments. Overall urban geochemical background values, and the consideration of run-off-related transport processes on pavements, are needed to develop effective management strategies of urban pavement soil pollution.
\end{abstract}




\section{Introduction}

The study of heavy metals as environmental pollutants, and their effect on different ecosystems and organisms, forms a major research field in environmental science (Alloway, 2013; Blume et al., 2011, 2016; Craul, 1999). In contrast to other pollutants (e.g. organic pollutants), heavy metals are far more widespread as they are natural components of the Earth's crust (Alloway, 2013). Anthropogenic activity, especially mining, industrial processes, traffic and transport, has led to a global increase in heavy metal concentrations in different environmental media like water, air and soil (Cai et al., 2015; Hakanson, 1980; Kowalska et al., 2018; Strode et al., 2009). Along with several emerging threats to the environment, the occurrence and behaviour of heavy metal contamination in soils poses significant challenges for soil ecosystems. Next to the extreme consequences of heavily contaminated soils (e.g. dead soil in former mining areas or industrial sites), the presence of heavy metals poses a risk for environmental security, food production, soil organisms and human health (Gałuszka et al., 2014; Strode et al., 2009). It is in this context, and the long-term research on heavy metals in soils, that many of today's management practices have become established. Taking Germany as an example, various regulations and laws deal with the topic of heavy metals and provide recommendations or legislated limits regarding concentrations for soils (e.g. federal soil protection ordinance; Bundesregierung, 1998; Blume et al., 2011).

In addition to the natural occurrence of heavy metals in soils, urban areas and their soils are particularly exposed to anthropogenic heavy metal sources. Emissions from industrial or home incinerators, traffic, garbage and construction materials could all be seen as the major sources of heavy metals in urban areas (Gunawardena et al., 2015; Craul, 1999; Manta et al., 2002; Sansalone et al., 1998; Defo et al., 2017; $\mathrm{Lu}$ and Bai, 2010; Mahanta and Bhattacharyya, 2011). Although it is possible to distinguish between point sources (e.g. industrial exhaust fumes) and diffuse sources (e.g. brake abrasion and corrosion), urban areas are often very densely built up and heavily exploited, resulting in extensive contamination throughout the area (Manta et al., 2002). Therefore, it is not surprising that the contamination status has become an important key feature of urban soils (Lehmann and Stahr, 2007). In contrast to the extensive research of heavy metal contamination in soils generally, the number of studies specifically investigating urban soils is still small (Burghardt et al., 2015; Schad, 2018).

Pavement joints, defined as the joint space between two or several pavement pieces and often filled by gravel, sand and organic material, fulfil important functions in urban environments. Basically, the question arises whether this material could be named urban soil, urban soil material or if it must be seen as an anthropogenic material without soil properties. In terms of the World Reference Base (WRB) for Soil Resources update in 2015 and the work on urban soils from
Burghardt (1995), pavement joint material could be defined as a part of the today's Technosol reference soil group or as part of urban soils in general (Burghardt, 1995; Burghardt et al., 2015; Schad, 2018; IUSS Working Group, 2015). In contrast to this, the pavement joint material and its anthropogenic origin differs from soil in its common definition in the most cases (e.g. soil functions or soil development; Blume et al., 2016). Regardless of this question of definition, pavement joints are a common feature in urban areas, like the paving on pavements, parking lots and access roads, and are used as a design element in public places. Compared to full sealing, they offer the advantage in that infiltration is ensured, which plays an important role in the management of urban run-off (especially storm water run-off; Sorme and Lagerkvist, 2002; Sansalone et al., 1998; Dierkes et al., 2005). In this context, they could also be seen as the only anthropogenic material which assumes important functions in extremely sealed inner urban areas, like the interaction with the atmosphere or as substrate for lower plants (Munzi et al., 2014; Seaward, 1979; Wang et al., 2020). Beside these important functions of pavement joints, pollution of joints material could pose several risks for the environment and humans. On the one hand, direct exposure to humans (e.g. playing children) or indirect exposure (e.g. urban dust) are thinkable. On the other hand, the potential transport of heavy metals from pavement joints to urban environments through run-off could affect water ecosystems or even agricultural land (e.g. deposition in floodplains during floods) far outside the urban centres. For these reasons, a pollution assessment of pavement joints becomes very important.

If one considers the pollution of urban soils or pavement joint material, however, then urban water management must also be included because, with surface and subsurface runoff, sealed or partially sealed surfaces and urban soils become a source of pollutants and may pollute urban waters. Therefore, a number of studies have focused on the water quality of surface run-off from urban areas that have been sealed or partially sealed (Drake and Bradford, 2013; Drake et al., 2014). Sorme and Lagerkvist (2002) examined waste water, and Sansalone et al. (1998) researched urban roadway storm water, with a focus on heavy metals. With a focus on urban water and effluent flow, Gilbert and Clausen (2006) studied drainage from different road surfaces, and Wessolek et al. (2009) examined drainage and pollution in sealed areas (Gilbert and Clausen, 2006; Wessolek et al., 2009). In summary, their findings show that surface run-off generally has high concentrations of heavy metals, hydrocarbons and further trace elements. However, the studies so far focused on parking areas or roads, and few studies mention the pavement joints of sealed or partially sealed surfaces as an urban interface, which can act as a source or sink of heavy metals (Dierkes et al., 1999, 2004, 2005). Furthermore, the pollution retention capability of pavement joints has mostly been determined in laboratory tests and not in the field (Fach and Geiger, 2005). Thus, the understanding of their long-term ca- 
pacity to retain heavy metals is still limited (Zhang et al., 2018). Apart from this, the question of whether already installed and used pavement joints, not only in car parks but also, for example, on pavements, contain accumulated heavy metals, still remains unclear (Dierkes et al., 2005).

In this paper, we report on a case study in the inner city area of Marburg (Hesse, Germany). The goals of our study were (1) the implementation of a heavy metal pollution assessment of pavement joints distributed in an inner city area, which, to our best knowledge, represents the first assessment considering diverse installed pavements and different sampling sites, and (2) to empirically depict possible sources and mobilities of heavy metals in pavement joints with a geospatial approach. The results of this study should improve the understanding of the heavy metal contaminations in pavement joints, which is necessary for the development of targeted urban land management strategies.

\section{Material and methods}

\subsection{Study area}

Our case study was conducted in the inner city area of Marburg (Hesse, Germany) located $75 \mathrm{~km}$ north of Frankfurt. The city of Marburg covers an area of $123.91 \mathrm{~km}^{2}$, including suburban areas (Hessisches Statistisches Landesamt, 2019; Fig. 1). With 67851 inhabitants $\left(620\right.$ persons km${ }^{-2}$; Hessian average: 297 persons $\mathrm{km}^{-2}$ ), the city of Marburg is the eighth-largest city in Hesse. The city is a central town in a rural region. Land use is divided into settlement areas (14.9\%), traffic areas $(7.5 \%)$ and vegetation containing green spaces, forests and agricultural areas (76.5\%; Hessisches Statistisches Landesamt, 2019). In contrast to the greater city area, the inner city consists of a medieval town centre with dense urban structures surrounded by residential, university and commercial districts. Traffic in the inner city is composed of local public transport, delivery traffic and individual traffic. Various main streets with high traffic volumes, especially during rush hours, alternate with low traffic zones and squares. Unfortunately, the database on traffic counts is very limited. A traffic census conducted by the Hessen Mobil road and traffic management agency in 2015 counted 44195 vehicles per $24 \mathrm{~h}$ (national highway B3, which passes the city from north to south), 11728 vehicles per $24 \mathrm{~h}$ (main road L3125, located in the south of Marburg) and 6145 vehicles per $24 \mathrm{~h}$ (main road L3092, located in the northwest of Marburg; Fig. 1; Hessen Mobil, 2015). All census points are located at city area entry roads. A second census conducted by the city administration in 2019 counted 13039 vehicles per $24 \mathrm{~h}$ for an inner city main road (Ketzerbach, along with sampling site KB; Bürgerversammlung Marbach, 2019). Out of this limited data set, the traffic volume in the city area of Marburg could be regarded as moderate compared to similar-sized cities. However, by concentrating traffic on certain main routes (resulting from urban development and the locations of the main employers), the traffic volumes reach levels above the limits at rush hours.

For the investigation of the spatial variability in the presence of heavy metals in pavement joints, we based our selection of possible study sites, firstly, on the traffic volume and, secondly, on the location of other possible sources of heavy metals. As traffic emissions, and especially brake abrasion or exhaust fumes, are regarded as the main sources of heavy metals on road sites, traffic volume and shielding from roads are important factors for the limitation of heavy metal emission (Duong and Lee, 2011; Gunawardena et al., 2015). However, other sources like house emissions, run-off and weathering of urban-installed materials (e.g. the pavement itself) should also be considered as possible sources (Gunawardena et al., 2015). Based on this, we aimed to investigate sites that exhibited (1) differences in traffic volume and (2) difference in the distance to roads and (3) are representative of the different types of paving and construction used within the inner city zone.

Following these criteria, the following six sampling sites were chosen across the inner city zone (Figs. 1, S2): Ketzerbach road $(\mathrm{KB})$ and Zwischenhausen road $(\mathrm{ZH})$ as parallel streets, while $\mathrm{KB}$ is an arterial road and $\mathrm{ZH}$ is a side road with very low traffic volume in a low traffic area; Elisabethkirche (EK), a square around a medieval church with no direct traffic but exposed on two sides to streets which carry a heavy volume of traffic; Audimax (AM) square and the parking area at the Schwanhof (FV), which are private places without traffic but are also exposed to streets; and Marktplatz (MP), which is the centre of the medieval district of Marburg, in a low traffic area with a high volume of pedestrian traffic. The site MP is located on a hillside that is clearly above the main traffic routes and completely shielded by buildings.

\subsection{Pavement joint material sampling}

This study aims to investigate the spatial variability in heavy metals in urban pavement joints at six study sites located in the inner city of Marburg and selected according to the above-mentioned criteria (Table 1). At each site, five composite pavement joint material samples from a $1 \mathrm{~m}^{2}$ pavement area were taken out of the pavement joints (Fig. S1). The sampling was carried out with a metal spatula (stainless steel) and plastic spoon. Material was collected from the joints to a depth of 2 to $7 \mathrm{~cm}$ in five places on each $1 \mathrm{~m}^{2}$ site. Each composite sample was stored in airtight plastic (PE) bags until further analyses. Sampling points were selected randomly, with the aim of covering the respective sampling area. At site FV and AM, the sampling points follow a straight line between street and the next main building. The distance to the nearest road was measured during fieldwork. The material structure in pavement joints was documented according to German soil classification standards (Ad-hoc AG Boden, 2005) and international soil classification standards (FAO, 2006; IUSS Working Group, 2015). In addition, 


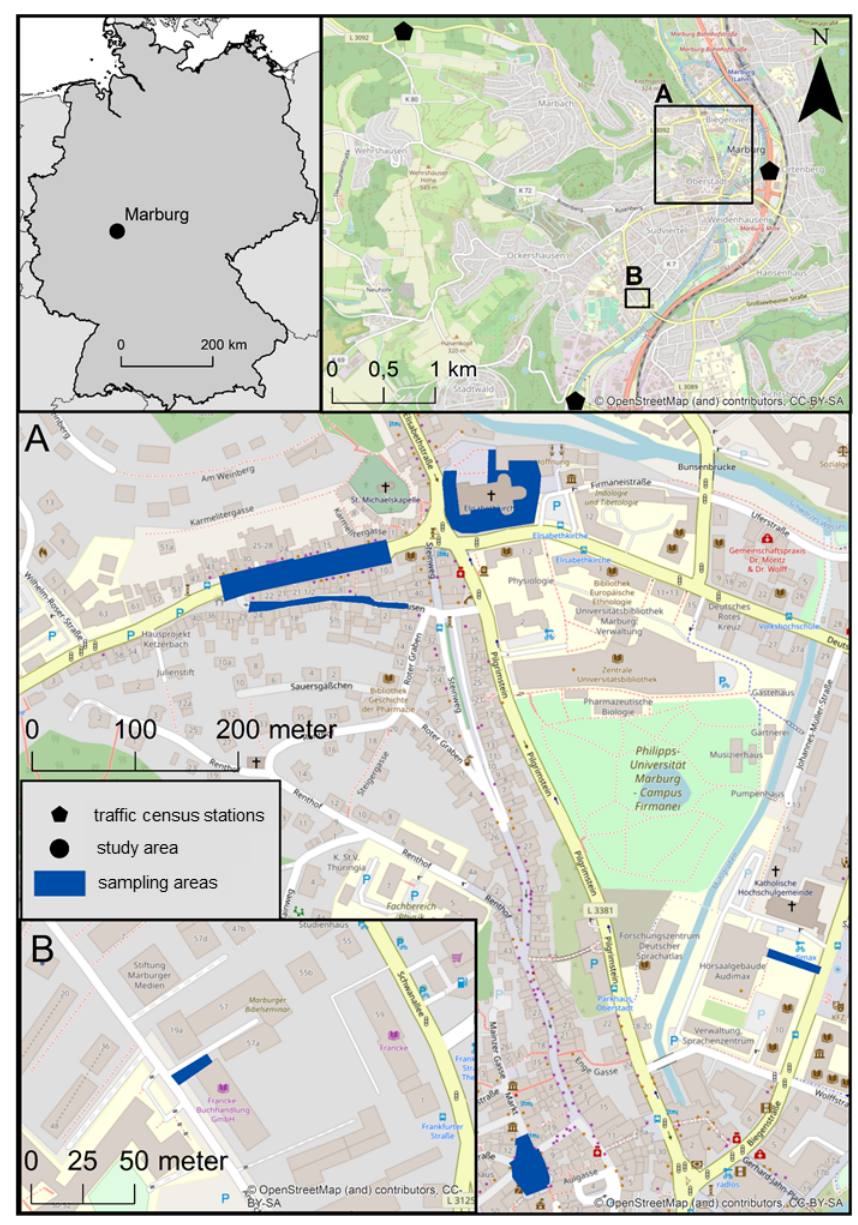

Figure 1. Study area map composition. (a) Inner city area of Marburg. (b) Sampling site Schwanhof (FV) in the southwestern area of the inner city. Data source: ( $)$ OpenStreetMap contributors 2020 and Hessian Administration for Soil Management and Geoinformation. Distributed under a Creative Commons BY-SA License.

the joint size and the size and type of installed stones were determined. Slope, potential run-off accumulation and absolute heights (metres above mean sea level) were determined by field measurement and additional height data from lidar measurements (Hessian administration for land management and geoinformation, 2019). Potential run-off accumulation was classified according to the following: $0-$ no accumulation (slopes $>2^{\circ}$; highest point at site); 2.5 - moderate accumulation (slope $<2^{\circ}$; no specific feature); and $5-$ high accumulation (no slope; lowest point at site, drainage gutter or discharge way). Furthermore, the vegetation coverage of pavement joints by mosses, lichens and small vascular plants was classified (no vegetation -0 ; very low coverage $<1 \%-$ 1; low coverage $<2 \%-2$; medium coverage $<10 \%-3$; strong coverage $<50 \%-4$; very strong coverage $>50 \%-$ $5)$. The distance from each sampling point to the next traffic frequented street (distance to next road) was measured dur- ing fieldwork. Substructure was finally determined by the removal of individual paving stones.

\subsection{Laboratory analyses}

All soil samples were oven-dried at $105^{\circ} \mathrm{C}$ for $24 \mathrm{~h}$. Afterwards, each sample was ground by mortar and sieved through a $2 \mathrm{~mm}$ stainless steel mesh. The content of the organic matter (OM) was measured by loss of ignition (DIN ISO 196843:2000-08; Deutsches Institut für Normung e.V., 2000). The $\mathrm{pH}$ value was determined in potassium chloride $(\mathrm{KCl})$, with a pH 91 electrode (WTW, Weilheim, Germany), in accordance with DIN ISO 10390:1997-05 (Deutsches Institut für Normung e.V., 2000).

Pseudo-total concentrations of the metals ( $\mathrm{Al}$ and $\mathrm{Fe}$ ), heavy metals (V, Cr, Co, Ni, Cu, Sn, $\mathrm{Cd}$ and $\mathrm{Pb}$ ) and the metalloid As was performed after the digestion of a $1 \mathrm{~g}$ prepared subsample with $20 \mathrm{~mL}$ aqua regia $(12.1 \mathrm{M} \mathrm{HCl}$ and 14.4 $\mathrm{MHNO}_{3}$; ratio $1: 3$; DIN ISO 11466:2006-12). Metal content was quantified with an inductively coupled plasma-mass spectrometry (ICP-MS; XSERIES 2; Thermo Fisher Scientific, Bremen, Germany). The ICP-MS system was calibrated with a certified multi-element standard solution (ROTI ${ }^{\circledR}$ STAR; Carl Roth GmbH, Karlsruhe, Germany). Each digest of a soil sample was measured three times and averaged. The resulting mean metal concentrations were converted into units $\left(\mathrm{mg} \mathrm{kg}^{-1}\right)$. Relative standard deviation (RSD) was quantified for all single measurements after threefold measurements to account for data reproduction and the effects of heterogeneous matrixes (Weihrauch, 2018; Voica et al., 2012). Data with an RSD $\geq 20 \%$ were excluded from further evaluation (Thomas, 2001).

\subsection{Statistics and data evaluation}

Basic statistical operations were carried out using Microsoft Excel 2016 (Microsoft, Redmond, USA), R (R Core Team, 2019) and RStudio (Version 3.5.3; RStudio Inc.; Boston, MA, USA). Additional analyses of height data from lidar measurements were carried out with ArcGIS (Esri, Redlands, USA) and QGIS (QGIS Development Team).

A major problem during the risk assessment for urban soils and pavement joint material is the absence of urban geochemical background values of heavy metal contamination. Natural soils and anthropogenic urban soils are only hardly comparable in terms of soil development or soil processes (Burghardt et al., 2015). Out of this circumstance, we decided to perform a three-step risk assessment based on the (1) comparison of heavy metal concentrations (given in $\mathrm{mg} \mathrm{kg}^{-1}$ ) with worldwide values, (2) comparison with the available legal requirements and (3) comparison with regional geochemical background values from natural soils and soil substrate. As a first approach, however, due to the lack of comparative values, there is only the possibility to attempt an approximation, which is also done in order to enable compar- 


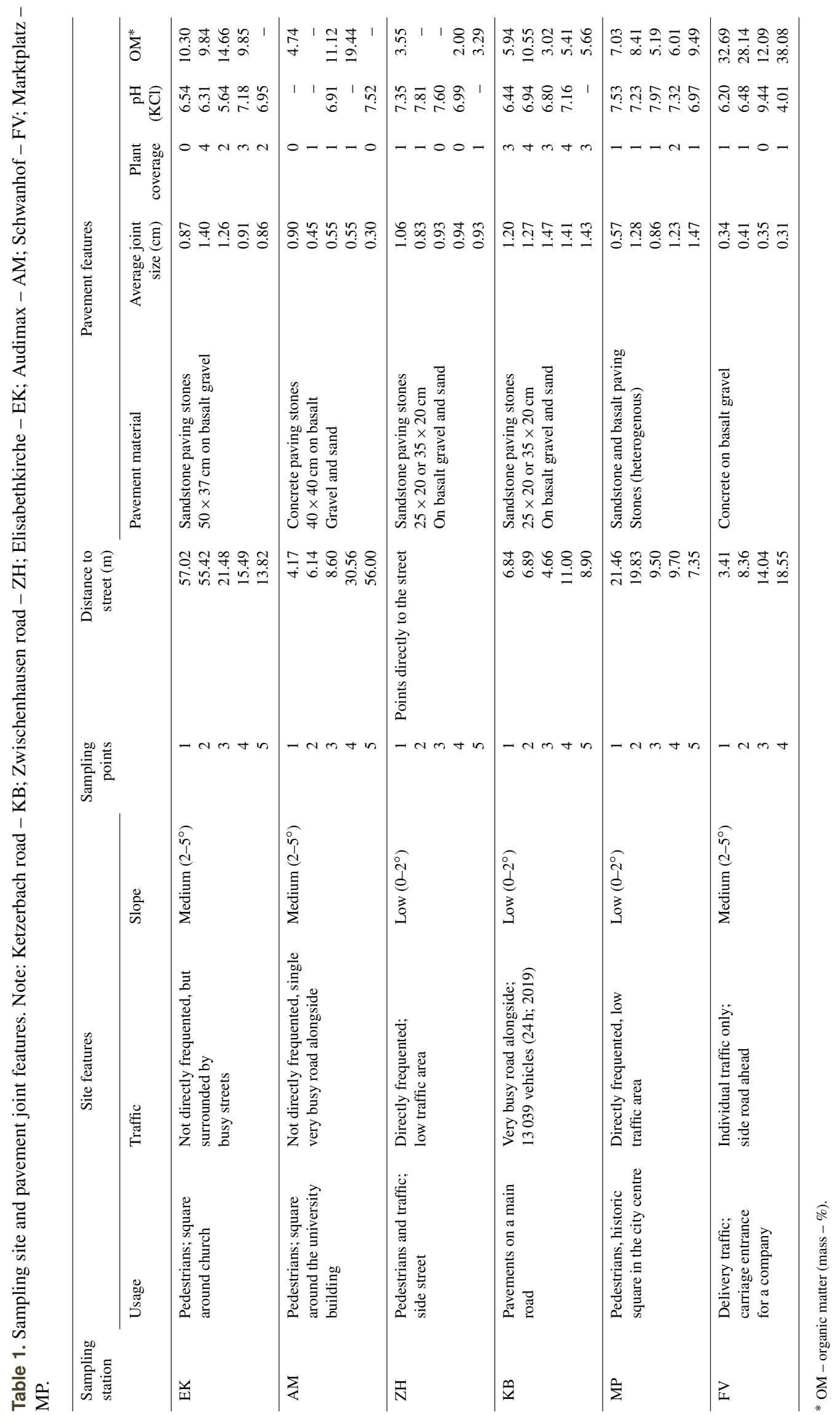


isons with other studies. For step one, we took the worldwide general levels of heavy metal and metalloid concentrations for soil surface horizons (SHW; Kabata-Pendias, 2011) and the composition in the upper continental crust (UCC; Rudnick and Gao, 2003). The legal precautionary level (LPL) for residential areas and sandy substrate of natural soils (without land use differentiation) given by the German Federal Soil Protection Ordinance (Bundesregierung, 1998; Bund/Länderarbeitsgemeinschaft Bodenschutz, 2003) were applied in step two. Even if these values are comparatively old, they are nevertheless valid according to the legislation in Germany. Finally, we compare our data with regional geochemical background values from natural soils. Even though the pavement material is not comparable to natural soil, natural materials are used in its construction. For this reason, we have examined the materials used for most of the pavement joints in the study area. These materials are firstly the substructure of basalt gravel (origin - alkaline basalt; Vogelsberg, Westerwald mountains) and sand for the first filling of the pavement joints (origin - sand and gravel pits; Lahn valley). From this, we have calculated a geogenic background value $(\mathrm{GBH})$ by averaging the background values for soils from regional volcanogenic substrates $(n=94)$ and external sand substrates $(n=64)$ for topsoil and subsoil in Hesse (Friedrich and Lügger, 2011).

Besides the description of the spatial distribution based on basic data evaluation, we have calculated the exposure factor (ExF) according to Bąbelewska (2010) Eq. (1) as follows:

$y=\sum \frac{C_{n}-C_{\mathrm{av}}}{C_{\mathrm{av}}}$,

where $C_{n}$ is the content of heavy metal at a sampling point, and $C_{\text {av }}$ is the average content of heavy metal at the sampling site. This index is based on the absolute measurement data, without the inclusion of geochemical background content like other heavy metal pollution indices, and provides information in which, in a given study area, the highest metal loads are located (Kowalska et al., 2018). The ExF values were compared with absolute terrain heights given in metres (above sea level - a.s.l.) to proof possible metal transport and accumulation through surface run-off on pavements.

To further investigate the possible accumulation of heavy metal and their spatial variability in pavement joints, we tested for different correlations between our data set. Spearman correlation analyses and tests for normal distribution (Shapiro-Wilk test) were performed with the R-packages "graphics", "stats" and "corrplot" (R Core Team, 2019; Wei and Simko, 2017). Interpretation of significant $(p \leq$ $0.05)$ Spearman correlation coefficients (rSP) was carried out according to the following criteria: weak (rSP $0.4 \leq 0.6$ ), clear (rSP $0.6 \leq 0.8)$ and strong (rSP $>0.8$; ZimmermannJanschitz, 2014).

\section{Results and discussion}

\subsection{Pavement joint properties}

Pavement joints are common in urban and suburban areas; they are purely anthropogenic in origin and, therefore, linked to human settlement. The build-up material of pavement joints consists of mineral components (gravel and sand), organic components (organic matter) and artefacts (glass, waste and plastics). Based on their properties, it could be distinguished between the substructure of pavements and the anthropogenic material in pavement joints itself, which can be considered as an upper pavement structure.

The pavement joints in the inner city of Marburg are mainly built up sands with basaltic gravel. From the surface, starting with a thin layer $(<0.5 \mathrm{~cm}$ ) of organics (often mosses, lichens and single plants) and organic material, the major part is built up of sands or sandy loams, with organic material and artefacts (waste fragments and glass fragments). A layer of sand or basaltic gravel (partly mixed) follows further down, with concrete or mortar in a few places. Even if the pavement material or substrate could not be classified as a soil in common understanding, the WRB (2015) provides the possibility for classification of those materials. According to WRB classification system, each pavement joint could be classified as Ekranic, Urbic, and Isolatic Technosol (Arenic and Humic) or Linic, Urbic, Isolatic and Hyperskeletic Technosol (Arenic and Humic; IUSS Working Group, 2015). Overall, the material built up in pavement joints is very young and has not been undisturbed by conversion measures for long periods.

The average lateral joint size is $0.89 \mathrm{~cm}( \pm 0.15)$, with a vertical depth of $2-10 \mathrm{~cm}$. The most common pavement material installed is sandstone (natural paving stones), followed by concrete and basalt paving in different size ranges (Table 1). Plant coverage in joints is heterogenous and occurs in small or medium coverage classes (Table 1). Thus, organic matter varies widely, with a total average of $11.10 \%$ by mass and a standard deviation of $9.25 \%$. Maximum values above $30.0 \%$ by mass occur at single points at sampling station FV. The extent of variability is explained by the variety of growth upon pavement joints, the building age of the pavement areas and the joint size. For example, wide pavement joints with a massive growth of moss and other vegetation have a high OM content. However, younger, smaller joints, filled only with sand or brash, show overall less OM content. As pavement joints are affected by dust and even light plant growth, higher organic matter content is typical, like in urban soils (Lehmann and Stahr, 2007).

The $\mathrm{pH}$ in pavement joints ranges between 4.01 and 9.44 (average -6.97 ). These overall neutral to slight or medium alkaline properties can be traced back to the general surrounding of alkaline materials (e.g. plaster itself and concrete; Räsänen and Penttala, 2004; Björk and Eriksson, 2002). Additionally, the basaltic under bed could be another 
factor, as regional basaltic rocks are highly alkaline (Jung and Masberg, 1998). Like OM enrichment, this $\mathrm{pH}$ range is specific to urban soils (Lehmann and Stahr, 2007).

In general, these young anthropogenic materials, which partly fulfil the characteristics of urban Technosols, appear in a wide variety, resulting from different materials and construction conditions (e.g. size and substructure). Overall, pavement joints are individually small in size, but through their widespread occurrence, they account for a large proportion in urban areas, especially as the only interface between the atmosphere and urban substructure (e.g. in heavily sealed areas).

\subsection{Heavy metal pollution of pavement joints}

All 11 metals studied were detected in each of the samples taken and analysed via ICP-MS. In general, the relative standard deviation of metal concentrations ranging between $0.71 \%$ and $2.84 \%$ indicates that our data are clustered around mean values with a small overall variation. Only the content of the trace metals $\mathrm{Al}\left(35853.00 \mathrm{mg} \mathrm{kg}^{-1}\right)$ and $\mathrm{Fe}\left(65968.50 \mathrm{mg} \mathrm{kg}^{-1}\right)$ reached absolute maximum values. Both elements are ubiquitous in each of the soil and rock materials. In addition, the high values of $\mathrm{Al}$ and $\mathrm{Fe}$ are a result of the fact that the under bedding of each pavement is basaltic grit, which, when weathered, releases $\mathrm{Al}$ and Fe at an increasing rate through decay of the rock (Bain et al., 1980).

From the 11 metals measured, six heavy metals $(\mathrm{Cr}, \mathrm{Ni}$, $\mathrm{Cu}, \mathrm{Sn}, \mathrm{Cd}$ and $\mathrm{Pb}$ ) and the metalloid $\mathrm{As}$ will be included in the results analysis as they show comparatively high values. Additionally, global and local geochemical background values for natural soils and legal comparison values are available for these metals. Primarily, the concentrations decrease from $\mathrm{Sn}$ over $\mathrm{Ni}, \mathrm{Cr}, \mathrm{Cu}, \mathrm{Pb}$ and $\mathrm{As}$ to $\mathrm{Cd}$ (Table 2).

Starting with the general comparison on a global level, average and median concentrations of each heavy metal exceed the average concentration in natural soil surface horizons worldwide (Kabata-Pendias, 2011; Table 2). This circumstance is also based on the fact that the heavy metal concentrations also exceed the assumed metal concentration in the upper continental crust (Rudnick and Gao, 2003). In contrast, the As concentration is significantly higher than the average SHW value but lower than the UCC value. These comparisons are only possible to a limited extent, as these are very general global mean values, but they are necessary as proper background values for pavement joints or urban anthropogenic substrates and soils are lacking. A better approximation can be achieved by comparing the heavy metal concentrations with the geochemical background in Hessian soils (Friedrich and Lügger, 2011). The average concentration of $\mathrm{Cr}, \mathrm{Ni}, \mathrm{Cu}, \mathrm{Cd}$ and $\mathrm{Pb}$ exceeds the calculated GBH values, whereas As stays below the value. When summarised, the heavy metal loads in pavement joints are, on average, 3.6 (SHW), 4.4 (UCC) and $2.9(\mathrm{GBH})$ times greater than the comparative values and, in the case of Sn, 245.4 times greater than SHW and UCC.

This exceeding of the values is generally not surprising, as each sampling site is exposed to different anthropogenic heavy metal sources. Besides the release of heavy metals, either by dust or gas in urban areas through incineration, there are other traffic-associated sources (Bryan Ellis and Revitt, 1982; Duong and Lee, 2011). For example, Cd, Cr and Ni, as a product of combustion of fossil fuels, can reach pavement joints through emissions (Duong and Lee, 2011). $\mathrm{Pb}, \mathrm{Cu}$ and Sn are strongly associated with traffic emissions (fossil fuel) or the abrasion from brake pads and tyres (Duong and Lee, 2011; Yan et al., 2013). For the spatially narrow inner city area, both larger point sources and a large number of diffuse sources must be considered with this in mind, and the highest concentrations of heavy metals coincided with typical urban source patterns. Although increased contamination is typical for urban soils (Schad, 2018; Lehmann and Stahr, 2007), partial concentrations can also be attributed to the materials used in pavement construction. Jung and Masberg (1998) noticed high concentrations of $\mathrm{Ni}, \mathrm{Cr}$ and $\mathrm{Co}$ for mafic volcanic rocks from the Vogelsberg mountains, located next to the city of Marburg, which have important quarries for regional construction activities (Fach and Geiger, 2005).

In contrast to this significant excess of geochemical backgrounds, the heavy metal concentrations do not exceed any of the legal precautionary levels for residential areas (Bundesregierung, 1998). Only the maximum values of $\mathrm{Cr}$ and $\mathrm{Ni}$ and the third quartile value of $\mathrm{Ni}\left(168.3 \mathrm{mg} \mathrm{kg}^{-1}\right)$ are above the given LPL values and, therefore, approximately $25 \%$ of the samples. As the given LPL values are the legal basis for the need for action in case of soil contamination in Germany, the data indicate that there is no need for countermeasures on a legal basis. However, as the LPL values are on average 9.6 times greater than the mean values of $\mathrm{Cr}, \mathrm{As}, \mathrm{Cd}$ and $\mathrm{Pb}$ in pavement joints, it seems to be difficult to achieve a status in which action must be taken at the legal level. Apart from this, taking into account other values of the legislation without a direct need for action, like the preventative values for natural soils or preventative thresholds for sandy substrates, both values are exceeded by the average concentrations of $\mathrm{Cr}, \mathrm{Ni}$, $\mathrm{Cd}$ and $\mathrm{Pb}$ (Bundesregierung, 1998). Furthermore, the range of $\mathrm{Cr}$ and $\mathrm{Ni}$ concentrations were above the preventative values for playgrounds $\left(200 \mathrm{mg} \mathrm{kg}^{-1} \mathrm{Cr}\right.$; $70 \mathrm{mg} \mathrm{kg}^{-1} \mathrm{Ni}$; Bundesregierung, 1998) at five sampling points for $\mathrm{Cr}$ (27 sites for $\mathrm{Ni}$, respectively). Irrespective of the fact that there is no need for countermeasures at the legal level, the fact that the comparative values and less strict legal values were exceeded indicates that a potential risk for humans and urban and extraurban environments cannot be excluded. Further discussion about a first risk assessment for pavement joints is given in Sect. 3.5. 
Table 2. Summary of metal and heavy metal concentrations (given in $\mathrm{mg} \mathrm{kg}^{-1}$ ) in pavement joints compared to natural background levels and legislative values.

\begin{tabular}{|c|c|c|c|c|c|c|c|c|}
\hline \multicolumn{2}{|r|}{$n=29$} & $\mathrm{Cr}$ & $\mathrm{Ni}$ & $\mathrm{Cu}$ & $\mathrm{Sn}$ & As & $\mathrm{Cd}$ & $\mathrm{Pb}$ \\
\hline & & \multicolumn{7}{|c|}{$\mathrm{mg} \mathrm{kg}^{-1}$} \\
\hline Mean & & 157.1 & 160.2 & 101.7 & 560.2 & 3.9 & 1.2 & 61.4 \\
\hline Median & & 109.7 & 140.3 & 94.4 & 387.6 & 4.0 & 1.1 & 50.9 \\
\hline Min. & & 43.4 & 48.5 & 35.7 & 104.6 & 1.3 & 0.3 & 2.9 \\
\hline Max. & & 1290.3 & 474.3 & 252.5 & 3728.1 & 7.6 & 4.1 & 187.7 \\
\hline $\mathrm{SD}$ & & 220.6 & 97.4 & 54.9 & 647.1 & 1.4 & 0.8 & 43.5 \\
\hline SHW $^{\mathrm{a}}$ & Average content surface horizons worldwide & 60.0 & 29.0 & 38.9 & 2.5 & 0.67 & 0.41 & 27.0 \\
\hline $\mathrm{UCC}^{\mathrm{b}}$ & Composition in upper continental crust & 92.0 & 47.0 & 28.0 & 2.1 & 4.8 & 0.09 & 17.0 \\
\hline $\mathrm{GBH}^{\mathrm{c}}$ & Geochemical background in Hessian soils & 68.8 & 101.5 & 26.3 & - & 5.7 & 0.19 & 25.5 \\
\hline LPL $^{d}$ & Legal precautionary level for residential areas & 400.0 & 140.0 & - & - & 50.0 & 20.0 & 400.0 \\
\hline
\end{tabular}

\subsection{Spatial variability in heavy metal pollution}

Different studies dealing with the topic of heavy metal contamination of pavement or urban soils have noted the significant influence of (a) spatial traffic differences (e.g. traffic volume and braking points at crossings) and/or (b) land use (e.g. industrial sites versus parks) and/or, if considering urban runoff (especially storm water run-off), (c) the distance to inlets or other emission sources as the major drivers for spatial patterns of urban heavy metal pollution (Bryan Ellis and Revitt, 1982; Duong and Lee, 2011; Herngren et al., 2006; Tedoldi et al., 2017; Logiewa et al., 2020). Through the selection and distribution of our sampling sites and points, we can give results for the spatial distribution of heavy metals in pavement joints on two spatial levels, namely level one, with a differentiation between sampling sites located in the inner city area of Marburg, and level two, including the comparison of single sampling points at each site with its neighbourhood and distance to different heavy metal sources.

Comparing the individual metal concentrations on the spatial level one, the concentrations of $\mathrm{Cd}, \mathrm{Pb}$ and $\mathrm{Ni}$ exceed the SHW and UCC levels at each sampling site (Fig. 2). The average As values at each site range between the SHW and UCC level, whereas the average $\mathrm{Cr}$ values exceed both values at four sampling sites. Also, the regional geochemical background for natural soils is exceeded for all metals (except As) at the main number of sampling sites. Out of these findings, a general pollution of pavement joints in the inner city area could be concluded.

However, within this general pollution, differences between sampling sites and points occur. Maximal levels of $\mathrm{Cd}, \mathrm{Ni}, \mathrm{Cr}$ as well as $\mathrm{Sn}$ are reached at site $\mathrm{FV}$, followed by MP and AM. Although the median values are quite narrowly spaced, the differences become clear in the maximum values. Considering traffic emissions (a) or a specific land use (b) as the main sources of urban heavy metal pollution and accumulation in pavements, it is interesting that the maximum concentrations are reached at FV (sidewalk and private driveway at secondary road) and MP (historic market place; low traffic area). In both cases, no particular exposure to traffic or contamination-promoting land use (e.g. industry) can be identified. However, exposure to traffic could play an important role for sites AM and EK as both sites, though not used directly by vehicles, are exposed to major roads. In comparing the locations $\mathrm{KB}$ and $\mathrm{ZH}$, the heavy metal concentration at $\mathrm{KB}$ is 2.5 times the values from $\mathrm{ZH}$. This finding could be traced back to the higher traffic frequency at site KB (major road) in contrast to side road ZH (Manta et al., 2002). Individual differences between the five sampling points at site $\mathrm{KB}$ are explained by stop and go traffic as levels of $\mathrm{Cu}, \mathrm{Cd}$, and $\mathrm{Pb}$ are often higher in areas around traffic lights, and $\mathrm{Ni}$ and $\mathrm{Cu}$ are attributed to braking (Duong and Lee, 2011). The locations EK and MP are low traffic areas, and the highest concentration at EK is reached at EK-3, which is the nearest point to both heavily used streets (Fig. S2). The lowest concentration is reached at EK-5, a sample point which is shielded from the streets by the church and where traffic emission sources cannot fully reach, as Hagler et al. (2011) noted in their study. At site MP, the highest level is clearly reached at MP-4 and MP-5. They are the only sample points with higher concentrations. MP-4 is located directly in a rainwater drainage channel, and MP-5 is subject to a lot of surface run-off. At site AM, maximal values are reached for $\mathrm{Cr}$, $\mathrm{Ni}, \mathrm{Cu}$ and $\mathrm{Pb}$ next to the major street (AM-1 and AM-2; Fig. S2). As sampling site AM was a linear one, AM-5 (greatest distance to street) also shows higher values, especially for $\mathrm{Cd}$, and the second-highest pollution load index (PLI) is recorded at this site, whereas the other linear sampling site, $\mathrm{FV}$, reflects an alternative trend. At site FV, the highest con- 

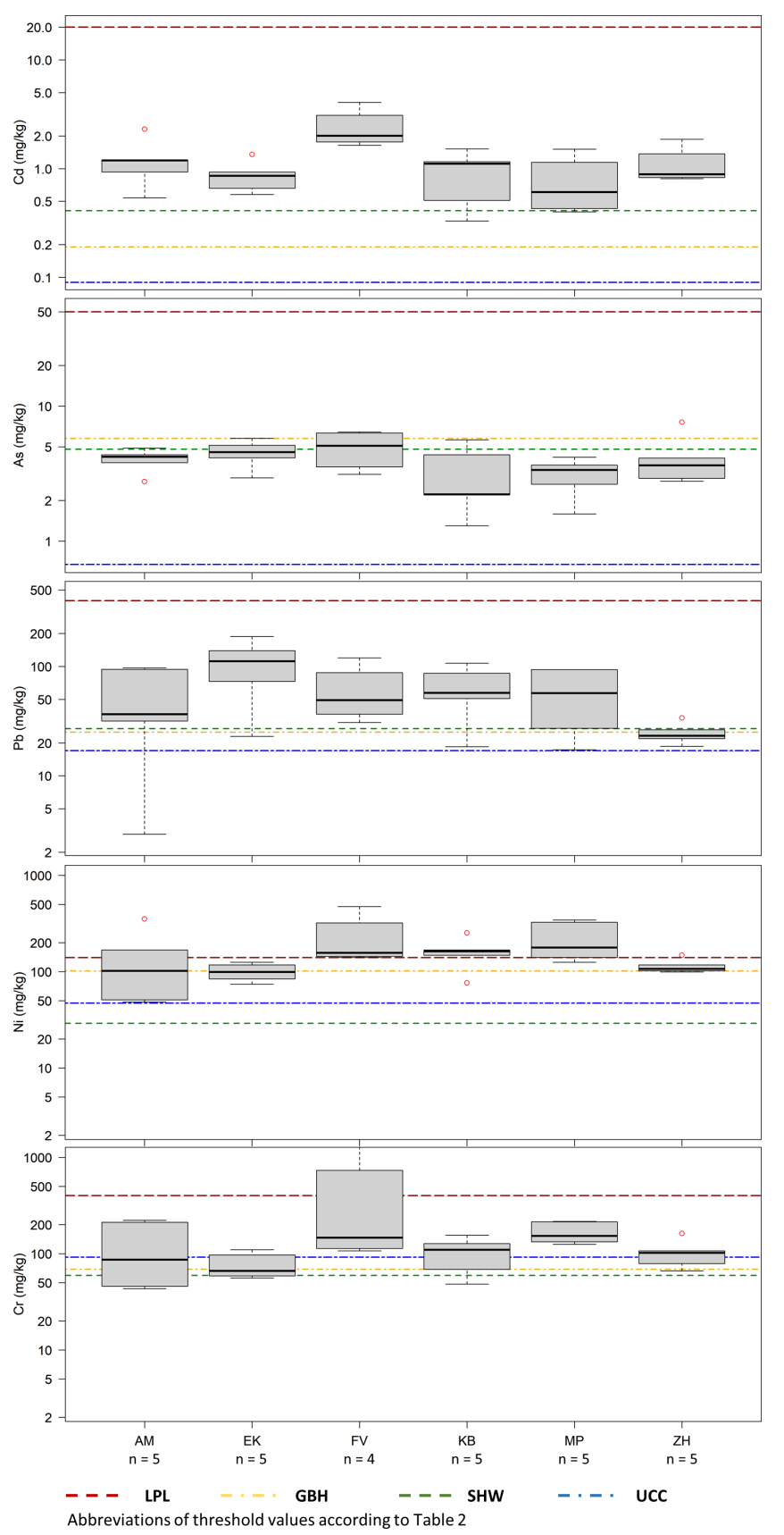

Figure 2. Concentrations of the heavy metals (given in $\mathrm{mg} \mathrm{kg}^{-1}$ ) $\mathrm{Cd}, \mathrm{Pb}, \mathrm{Ni}$ and $\mathrm{Cr}$, with the metalloid As, according to sampling sites and different thresholds according Table 2.

centration of each heavy metal and pollution index is FV-3 followed by FV-4. Both sites are located furthest from the road.

Considering maximum heavy metal loads, the highest concentrations are reached at point $\mathrm{FV}-3$ for $\mathrm{Ni}\left(474.3 \mathrm{mg} \mathrm{kg}^{-1}\right)$, $\mathrm{Cr} \quad\left(1290.3 \mathrm{mg} \mathrm{kg}^{-1}\right), \quad \mathrm{Sn} \quad\left(>3000 \mathrm{mg} \mathrm{kg}^{-1}\right)$ and $\mathrm{Cd}$ (4.1 $\mathrm{m} \mathrm{kg} \mathrm{k}^{-1}$ ), followed by MP-4 and MP-5 and AM-2 with additional higher loads. Critical legal maximum values for
$\mathrm{Ni}$ (residential area) are reached by $100.0 \%$ of sampling points at $\mathrm{FV}$ and $80.0 \%$ at $\mathrm{KB}$ and MP (Fig. 2). The legal maximum value for $\mathrm{Cr}$ (playground) is reached at a maximum of $40.0 \%$ of all points at site AM and MP. It could therefore be concluded that single pollution hot spots occur in the inner city area of Marburg. The origin of these hot spots cannot be attributed exclusively to traffic, as stated in the majority of other studies dealing with heavy metals in urban soils (Yan et al., 2013; Herngren et al., 2006; Duong and Lee, 2011; Bryan Ellis and Revitt, 1982).

The Spearman correlation between the distance from each sampling point to the next traffic-frequented street (distance to the next road), shows weak positive correlations for $\mathrm{Sn}$ and $\mathrm{Pb}$ in subordinate data (all sampling sites; Table 3). Additional single sampling, site-specific significant correlations occur at site $\mathrm{AM}$ for $\mathrm{Cd}$, at site $\mathrm{EK}$ for $\mathrm{Ni}$ and site $\mathrm{KB}$ for $\mathrm{Sn}$. Besides these results, the correlation between distance to the next road and the ExF is not significant for subordinate and specific data. Therefore, it can be concluded that traffic emissions do not seem to be the main reason for the spatial distribution of heavy metals.

Another possible factor in understanding the distribution patterns could be urban drainage and surface run-off, including storm water run-off, as drainage could be a possible transport medium for heavy metals on paved areas (Gilbert and Clausen, 2006; Tedoldi et al., 2017). The sites AM and FV are examples in which the influence of slope and drainage for the distribution of heavy metals in pavement joints can be monitored. The highest individual metal concentration and ExF values are reached at the lowest section in these areas and near drainage gutters (Fig. 3). FV has a consistent slope from FV-1 to FV-3. Only FV-4 is located beyond the gutter on a flat section. Site AM presents a similar case because sample point AM-2, with higher concentrations, is also the lowest point and near the gutter. The samples were taken in a straight line from AM-1 near a road, over a gutter to AM2 and across a permanent incline to a second gutter (AM-5) in front of a building.

An additional Spearman correlation analysis was carried out to test these relationships between potential run-off accumulation and absolute height (above mean sea level) of each sampling point, with metal concentrations and the $\operatorname{ExF}(\mathrm{Ta}-$ ble 4).

Overall, strong positive correlations $(p<0.05)$ were found between run-off accumulation value and the ExF and $\mathrm{Cr}$ values. Additional clearly positive correlations were found for $\mathrm{Ni}, \mathrm{Cu}, \mathrm{Sn}, \mathrm{As}$ and $\mathrm{Pb}$ (Table 4). However, the correlation with absolute heights (metres above mean sea level) shows no clear subordinate correlations. For the sites AM, MP and FV, a clear trend is apparent when plotting absolute heights against ExF data (Fig. 3). The highest pollution loads are reached at the sites clearly at the lowest point. In the case of site MP, the highest ExF value is reached by the sampling point with largest terrain height. As concluded from fieldwork, sampling point MP-5 is higher but has the high- 

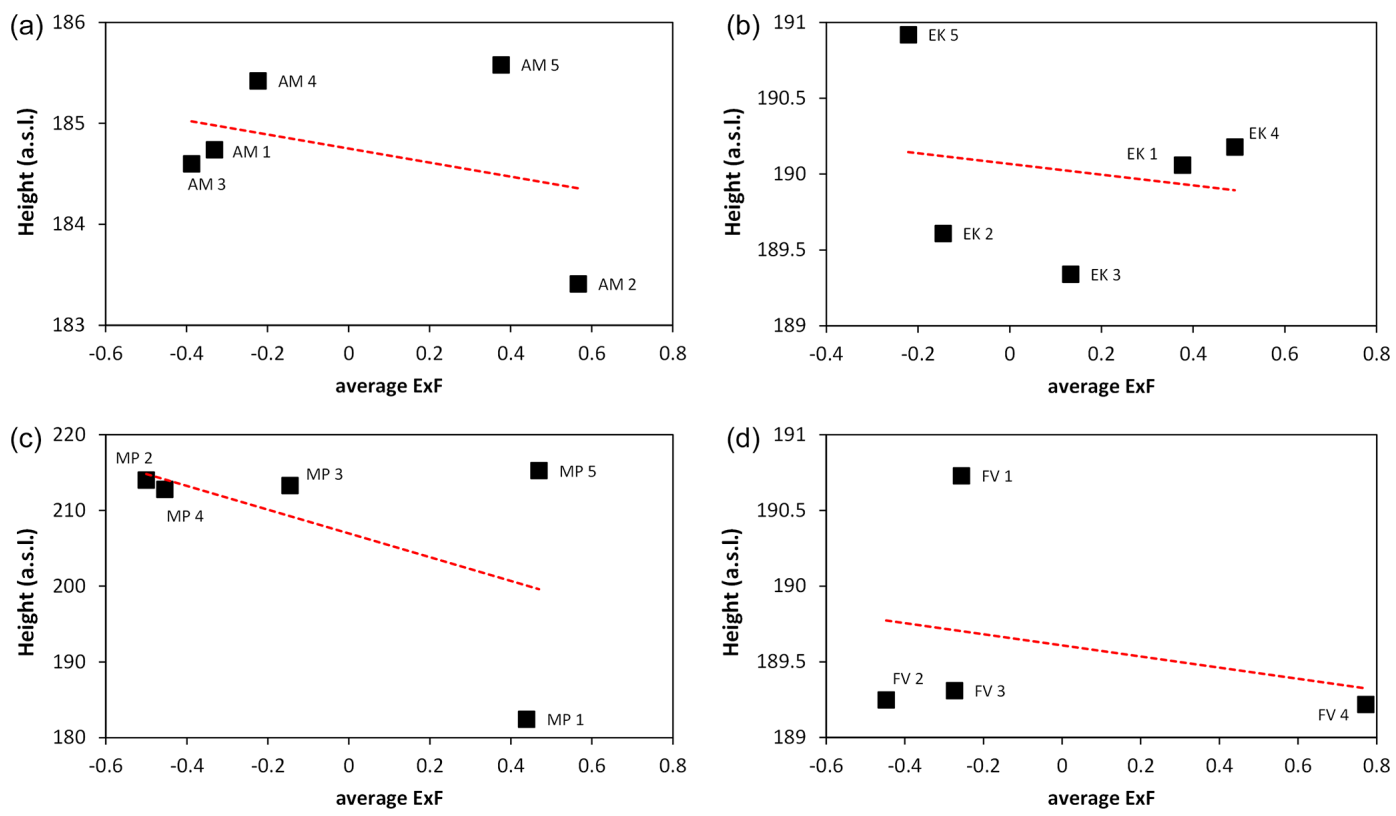

Figure 3. Exposure factor (ExF) according to sampling point height (metres above mean sea level) for all sampling sites with significant height differences. (a) Sampling site AM; (b) sampling site EK; (c) sampling site FV; (d) sampling site MP. Linear trend is shown as a red dashed line.

est potential run-off accumulation as it is reached by a larger surface run-off area above and is located next to discharge points in the pavement or drainage gutters. In the case of site EK-1 and EK-4, with medium terrain height for the site, they show highest ExF values, which could also be traced back to the location of drainage gutters on site. This result is contrary to other findings, as Tedoldi et al. (2016) reported the highest accumulation of heavy metals at inflow points as a consequence of filtration capacity.

\subsection{Accumulation and mobility tendencies of heavy metals in pavement joints}

Each sampled pavement joint in the inner city of Marburg shows an alkaline soil milieu and high organic matter (OM) content (Table 1). Additional correlation analyses of $\mathrm{OM}$ content and $\mathrm{pH}$ with metal concentration reveal two groups with significant relationships $(p=<0.05)$ but opposite and reversed conditions (Fig. 5). Group 1, including the trace metals $\mathrm{Al}$ and $\mathrm{Fe}$, shows slightly weak negative correlations with $\mathrm{OM}$ and weak positive correlations with $\mathrm{pH}$. Accordingly, group 2, including $\mathrm{Cu}, \mathrm{Sn}, \mathrm{As}, \mathrm{Cd}$ and $\mathrm{Pb}$, shows clear positive correlation with $\mathrm{OM}$ and weak negative correlation with $\mathrm{pH}$. The weak negative correlations are consistent with the findings from urban soils in which no significant correlation occurs (Manta et al., 2002) Additional clear to strong positive correlations between metals themselves appear between $\mathrm{Al}, \mathrm{Fe}, \mathrm{Cr}$ and $\mathrm{Ni}$. In contrast, there are very weak negative and positive correlations of these metals with the group of $\mathrm{Cu}, \mathrm{Sn}, \mathrm{As}, \mathrm{Cd}$ and $\mathrm{Pb}$. In addition, $\mathrm{Cu}, \mathrm{Sn}, \mathrm{As}, \mathrm{Cd}$ and $\mathrm{Pb}$ have strong to weak positive correlations among themselves. From these findings, based on significant inter-element relationships, the data set could be divided into group $1(\mathrm{Al}$, $\mathrm{Fe}, \mathrm{Cr}$ and $\mathrm{Ni}$ ) and group $2(\mathrm{Cu}, \mathrm{Sn}, \mathrm{As}, \mathrm{Cd}$ and $\mathrm{Pb})$. Other authors suggest that strong inter-element relationships could be traced back to a combined metal pollution from similar long-term sources (Manta et al., 2002; Lu and Bai, 2010). Therefore, group 1 and group 2 metals may have a different origin or different controlling factors (Dragović et al., 2008).

Next to those inter-element relationships, different correlation clusters with $\mathrm{OM}$ and $\mathrm{pH}$ could allow suggestions about metal, metalloid and heavy metal retention in pavement joints as both values could be important controlling factors. First of all, the pavement joint substrate, built up from sands and coarse gravel with artefacts, allows only poor adsorption of heavy metals on clay minerals, silt or pedogenic oxide surfaces (Blume et al., 2016; Alloway, 2013). In contrast, the high content of OM could lead to the sorption on humic substances and the formation of metal-humus complexes (Herms and Brümmer, 1984; Alloway, 2013). In this context, we interpret the clear to strong positive correlation between group 2 metals $(\mathrm{Cu}, \mathrm{Sn}, \mathrm{As}, \mathrm{Cd}$ and $\mathrm{Pb}$ ) and $\mathrm{OM}$ as being evidence of those processes. The adsorption was also found in urban soils for $\mathrm{Cu}$ and $\mathrm{Pb}$ but not for $\mathrm{Cd}$ (Mahanta and Bhattacharyya, 2011). Also, Defo et al. (2017) found a major influence of $\mathrm{OM}$ on the retention of $\mathrm{Pb}$ and $\mathrm{Cd}$ in urban soils (Defo et al., 2017). These different findings stayed in line with the fundamental role of $\mathrm{OM}$ for $\mathrm{Pb}$ and $\mathrm{Cu}$ sorption in soils (Lee et al., 1998; McLaren et al., 1983). The overall neutral to alkaline $\mathrm{pH}$ milieu (6.97 total average) supports a 
Table 3. Spearman correlation between distance to next road, exposure factor (ExF) and metal concentrations.

\begin{tabular}{|c|c|c|c|c|c|c|c|c|c|c|c|}
\hline \multirow[t]{2}{*}{ Variable A } & \multirow[t]{2}{*}{ Variable B } & \multicolumn{2}{|c|}{ All sampling sites } & \multicolumn{2}{|l|}{$\mathrm{AM}^{\mathrm{a}}$} & \multicolumn{2}{|l|}{$\mathrm{EK}^{\mathrm{a}}$} & \multicolumn{2}{|l|}{$\mathrm{KB}^{\mathrm{a}}$} & \multicolumn{2}{|l|}{$\mathrm{MP}^{\mathrm{a}}$} \\
\hline & & Spearman $\rho$ & $p$ & Spearman $\rho$ & $p$ & Spearman $\rho$ & $p$ & Spearman $\rho$ & $p$ & Spearman $\rho$ & $p$ \\
\hline Distance to & $\mathrm{OM}^{\mathrm{b}}$ & 0.50 & 0.01 & 1.00 & 0.00 & 0.00 & 1.00 & 0.10 & 0.87 & -0.10 & 0.87 \\
\hline next road (m) & $\mathrm{pH}$ & -0.15 & 0.50 & 1.00 & 0.00 & -0.20 & 0.80 & 0.80 & 0.20 & 0.30 & 0.62 \\
\hline & $\mathrm{ExF}^{\mathrm{c}}$ & 0.12 & 0.55 & 0.20 & 0.78 & 0.60 & 0.35 & 0.70 & 0.23 & -0.40 & 0.51 \\
\hline & $\mathrm{Cr}$ & -0.21 & 0.27 & -0.60 & 0.28 & -0.70 & 0.19 & -0.60 & 0.28 & -0.60 & 0.28 \\
\hline & $\mathrm{Ni}$ & -0.27 & 0.16 & -0.60 & 0.28 & -0.90 & 0.04 & -0.60 & 0.28 & -0.70 & 0.19 \\
\hline & $\mathrm{Cu}$ & 0.32 & 0.09 & -0.50 & 0.39 & 0.60 & 0.28 & 0.20 & 0.75 & -0.40 & 0.50 \\
\hline & $\mathrm{Sn}$ & 0.52 & 0.00 & 0.70 & 0.19 & 0.60 & 0.28 & 0.90 & 0.04 & -0.50 & 0.39 \\
\hline & As & 0.20 & 0.29 & 0.20 & 0.75 & -0.50 & 0.39 & -0.20 & 0.75 & -0.20 & 0.75 \\
\hline & $\mathrm{Cd}$ & 0.07 & 0.73 & 0.90 & 0.04 & 0.60 & 0.28 & 0.80 & 0.10 & -0.70 & 0.19 \\
\hline & $\mathrm{Pb}$ & 0.58 & 0.00 & 0.40 & 0.50 & 0.60 & 0.28 & 0.50 & 0.39 & -0.40 & 0.50 \\
\hline
\end{tabular}

${ }^{\mathrm{a}}$ Sampling sites; ${ }^{\mathrm{b}}$ organic matter; ${ }^{\mathrm{c}}$ exposure factor.

Table 4. Spearman correlation between run-off accumulation value, exposure factor $(\mathrm{ExF})$ and metal concentrations for sampling points at sites significant height differences (sites - AM, FV, and MP).

\begin{tabular}{llrr}
\hline Variable A & Variable B & Spearman $\rho$ & $p$ value \\
\hline Run-off & $\mathrm{ExF}^{*}$ & 0.80 & 0.00 \\
accumulation & $\mathrm{Cr}$ & 0.80 & 0.00 \\
value & $\mathrm{Ni}$ & 0.76 & 0.00 \\
& $\mathrm{Cu}$ & 0.76 & 0.00 \\
& $\mathrm{Sn}$ & 0.65 & 0.01 \\
& $\mathrm{As}$ & 0.61 & 0.02 \\
& $\mathrm{Cd}$ & 0.35 & 0.21 \\
& $\mathrm{~Pb}$ & 0.68 & 0.00 \\
\hline
\end{tabular}

$*$ ExF - exposure factor.

fixation of metals by specific bindings since unspecific bonds and dissolutions only occur at more acidic $\mathrm{pH}$ values (Herms and Brümmer, 1984; Blume et al., 2016). Comparing the opposite relationships of group 1 and group 2 metals with additional inter-element relationships, we conclude that there is a medium-fixated group of metal complexes including $\mathrm{Al}, \mathrm{Fe}$, $\mathrm{Cr}$, and $\mathrm{Ni}$ with weaker relationships to the controlling factors $\mathrm{OM}$ and $\mathrm{pH}$ (medium potential mobility; less adsorption tendency) and a partially more fixed group of $\mathrm{Cu}, \mathrm{Sn}, \mathrm{As}, \mathrm{Cd}$ and $\mathrm{Pb}$ with stronger relationships to the controlling factors (low potential mobility; strong adsorption tendency).

Out of the correlation analyses and the additional widespread spatial pollution with comparatively high concentrations of different metals in pavement joints, an accumulation of metals in pavement joints could be stated. Available sorbents, the alkaline environment and a constant supply of heavy metal emissions from a minimum of two different main sources, provide suitable conditions for pollution accumulation. This point deserves special attention, as other authors have noted heavy metal enrichment by organic material, especially in gutters, which would demonstrate a link between transport by water and accumulation at run-off gath-

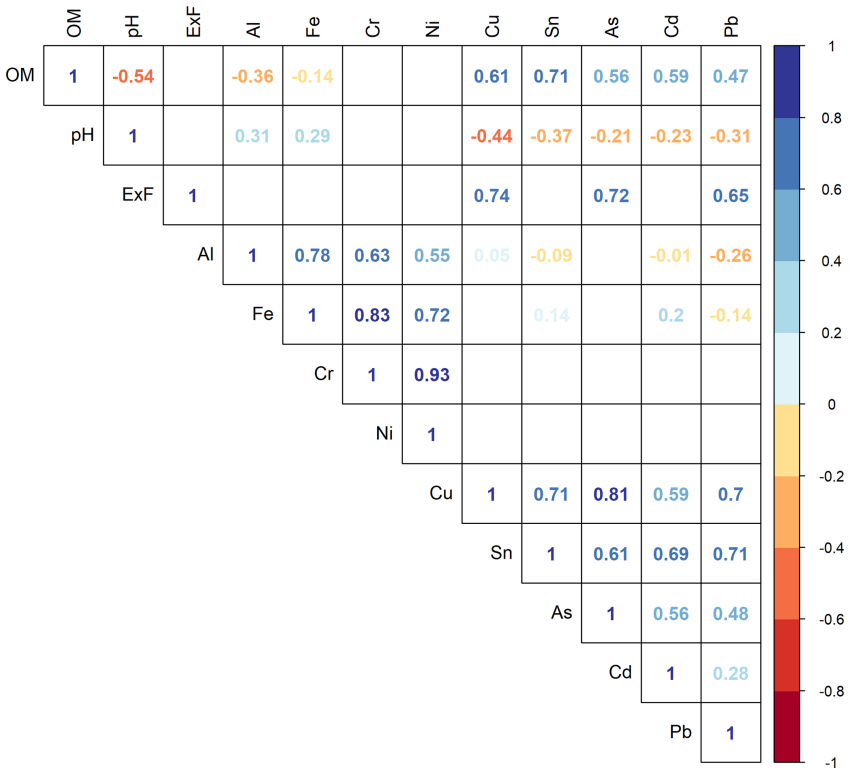

Figure 4. Spearman correlation matrix for organic matter (OM), $\mathrm{pH}$, exposure factor $(\mathrm{ExF})$ and elemental concentrations in pavement joints. Spearman's $\rho$ is displayed in the grid if the correlation is significant ( $p$ value $<0.05$ ). Positive correlations in blues; negative correlations in reds.

ering points (Bryan Ellis and Revitt, 1982). Even if the major heavy metal share with the metalloid As could be seen as being accumulated and more or less fixed by $\mathrm{OM}$ and $\mathrm{pH}$ conditions, this accumulation can become especially problematic in the case of strong surface storm water run-off through precipitation. If urban surface or storm water run-off is regarded as a major driver for heavy metal transport and accumulation at the lowest points, further transport after the infiltration in pavement joints seems to be possible. Particle uptake and transport as suspended load as a major process and the transport as dissolved metals in surface run-off for the less fixed metal group as a secondary process could be possible (Gilbert and Clausen, 2006). Applying this on a 
larger scale, and considering urban pavements as pollution sources for the environment out of urban areas, polluted urban run-off could provide a link between both systems as especially storm water run-off is discharged directly into receiving waters from urban areas, so less polluted environments like rivers, wetlands and floodplains in downstream areas may also be affected. Therefore, a risk for agricultural land in alluvial zones, and for river ecosystems, is conceivable.

\subsection{Contamination pathways and risk assessment for heavy metal pollution in urban pavement joints}

Heavy metals as environmental pollutants could pose a wide variety of potential risks for different ecosystems, plants and animals (Alloway, 2013; Blume et al., 2011, 2016; Craul, 1999). Even if different metals act as important trace metals (e.g. $\mathrm{Ni}, \mathrm{Co}$ and $\mathrm{Cu}$ ) for organisms, increased or excessive concentrations in combination with the hazardous and toxic properties of other metals (e.g. As and Cd) lead to the need for risk assessments of heavy metals in the environment (Alloway, 2013).

Common practices developed for risk assessment of heavy metal pollution in natural soils are based on the consideration of various direct and indirect contamination and exposure pathways (e.g. soil-human and soil-plant; Blume et al., 2016). Additionally, exposure time and potential doses or uptake quantities are important factors when evaluating potential risks. Furthermore, negative influences on soil functions must be assessed (Gałuszka et al., 2014; Strode et al., 2009).

Often rules and limit values from legislation can be used for this purpose, such as the precautionary values for soils from the German Federal Soil Protection Act applied in this study (Bundesregierung, 1998; Blume et al., 2011). Various geochemical indices (e.g. geoaccumulation index, pollution load index and ecological risk index) are also applied to assess the potential contamination (e.g. ecological risk index; Kowalska et al., 2018):

In the case of urban pavement joints and their contamination with heavy metals, common tools and practices need to be reconsidered for a risk assessment. Geochemical indices for natural soils based on geochemical background values cannot be applied purposefully due to the lack of data and studies, as there is no basis for comparison. Limit and threshold values based on legislation can be applied but may underestimate potential risks, as inner urban areas are preferred living areas for humans and lead to long-term exposure to urban pollutants (United Nations, 2019). The combination of expected long-term or lifetime exposures and the worldwide increase in urban population highlights the necessity for a first risk assessment on pavement joint pollution (United $\mathrm{Na}$ tions, 2019).
Under the considerations of the given limitations of this study, we conclude the following main issues as being important for a general risk assessment (regarding Sect. 3.13.4): (a) metal contamination of urban pavement joint material with single spatial hot spots from multiple sources is given, even if legal precautionary levels are only exceeded by single maximum concentrations, (b) spatial distributions of metal concentration are given, indicating inner urban transport and accumulation of metals through surface run-off, and (c) pavement joint properties and statistical relationships are given, indicating fixation and accumulation tendencies for heavy metals in pavement joints.

When combining these findings with previous research, each contamination pathway starts with a potential source for heavy metals in urban areas. Even if this study can only give limited estimations on possible sources (e.g. no direct relationship to traffic emissions), different authors take various potential sources into account (e.g. emissions and construction material; Gunawardena et al., 2015; Craul, 1999; Manta et al., 2002; Sansalone et al., 1998; Defo et al., 2017; Lu and Bai, 2010; Mahanta and Bhattacharyya, 2011). Independent of the specific source, three different processes result from the presented data, which could be responsible for the observed accumulation (Fig. 5a), namely rainfall followed by surface run-off or infiltration on the one hand and airflow on the other hand. Starting with processes which require water as a transport medium, the transport of metals in a dissolved form or as suspension freight is conceivable. The possible flow distance is limited at the surface by the network of drainage units (e.g. gutters and gullies) and the comparatively high infiltration capacity of paved areas. Infiltration rates from the literature for different urban substrates range between 80 and $2000 \mathrm{~cm} \mathrm{~h}^{-1}$ (permeable interlocking concrete pavers; Bean et al., 2007) or 1.2 and $577.1 \mathrm{~cm} \mathrm{~h}^{-1}$ (pervious concrete; Chopra et al., 2010) and could be named as highly heterogenous based on the structure properties. This transport processes, especially during heavy rainfall events due to the high sealing in inner urban areas, can lead to the accumulation and deposition of metals in the pavement joint material and to initial accumulation in puddles or further transport into the urban sewage system. In addition, transport by airflow is conceivable as a further process, especially under dry conditions. High heavy metal contents in road dust are already known (Christoforidis and Stamatis, 2009; Duong and Lee, 2011; Logiewa et al., 2020). Under dry and windy conditions, pavement joints, which are mostly open and not covered with plants, can theoretically lead to a constant alternation of transport and deposition, which can be intensified by urban wind systems and heat islands (Grimmond and Oke, 1998; Arnfield, 2003; Vardoulakis et al., 2003).

With the consideration of these transport or migration processes, direct and indirect exposures, additionally divisible by spatial units, could occur for heavy metals in pavement joints (Fig. 5b). 
(a)

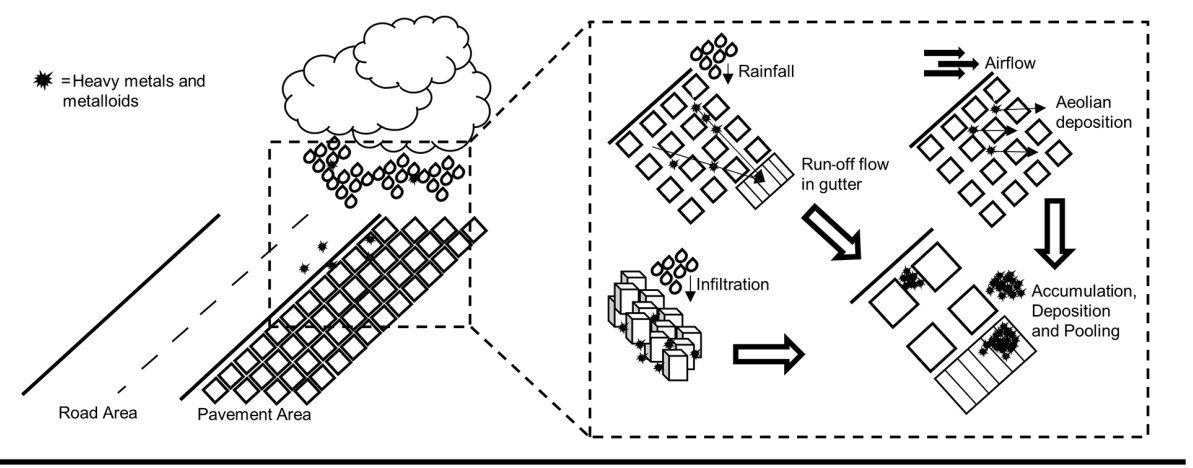

(b)
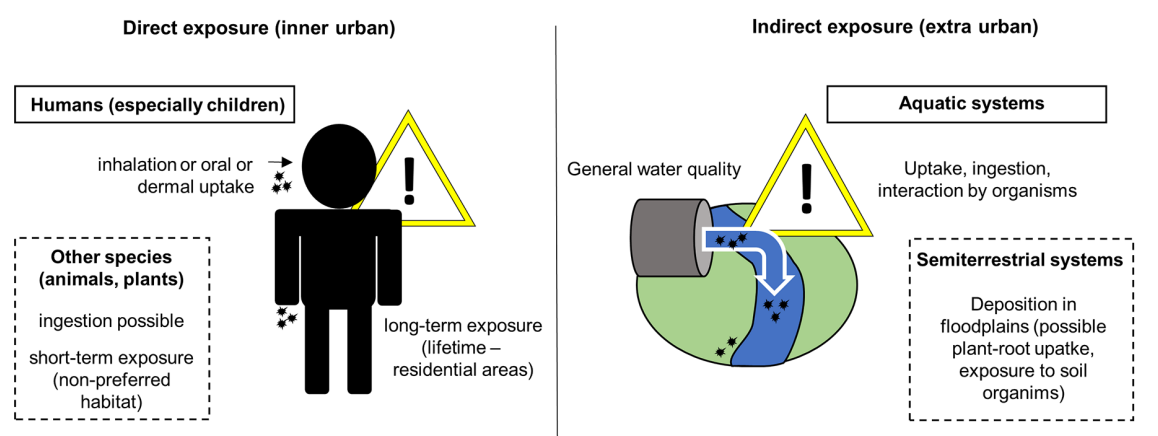

Figure 5. Risk assessment for heavy metal pollution in urban pavement joints. (a) Potential contamination pathways of heavy metals in urban pavement joints. (b) Potential risk exposures from heavy metals from urban pavement joints.

For inner urban areas, direct exposure to humans, especially to children, through inhalation or oral or dermal uptake is conceivable. From the legislation side, no trigger or action thresholds are exceeded by the detected heavy metal concentrations, which indicates a low exposure risk (Bundesregierung, 1998; Blume et al., 2016). In contrast, the low exposure risk could be higher than assumed when taking the long-term exposure for humans into account. As pavement joints are primarily built in residential areas, those areas are simultaneously preferred living areas, which makes a daily exposure possible for a lifetime (Luo et al., 2012; Li et al., 2014). The direct exposure to other species like animals or plants is more difficult to assess, since urban areas are not the preferred habitat of most species here. The uptake of metals is basically conceivable; the risk of damage is probably low (Munzi et al., 2014; Wang et al., 2020).

In addition to these potential risks, there are other indirect exposures outside the inner urban area. As a result of the transport processes mentioned above, heavy metals can quickly pass through waste water into rivers, especially during heavy rainfall events. The consequences of heavy metal inputs into aquatic systems from urban or other sources (e.g. mining sites) are well known (Sansalone et al., 1998; Sorme and Lagerkvist; 2002; Atanackovic et al., 2013). As a result, the quality of the water can deteriorate significantly, and there are many negative influences on aquatic organisms (Atanackovic et al., 2013; Sakson et al., 2018; Zhang et al., 2020). In addition, heavy metals may also reach semiterrestrial systems (e.g. floodplains) and their soils and enter further contamination paths (e.g. plant-root uptake) through flooding (Miller, 1997).

The potential contamination pathways and risks posed by heavy metal contamination in urban pavement joints can be described as manifold, which leads to a clear demand for more research in this field in order to conduct precise risk assessments. Based on the present study, we estimate the risk of direct exposures within our study area to be low. Nevertheless, there is also a risk for non-urban areas, which should not be neglected. More intensive use of urban areas during increasing extreme weather events caused by climate change (e.g. heavy rain, flooding and heat) can intensify the risk of heavy metal discharge and the negative impacts on important aquatic ecosystems (IPCC, 2018). Finally, the question arises as to whether the risk for urban ecosystems and urban habitats and for functions of the pavement joints (e.g. infiltration and heavy metal retention) should be reassessed in the future.

\section{Conclusions}

In our study, pavement joints, mentioned as an important part of the urban soils, were found to be polluted by $\mathrm{Cr}, \mathrm{Ni}, \mathrm{Cu}$, $\mathrm{Cd}$ and $\mathrm{Pb}$ at each sampling site, as shown by absolute concentrations. Despite the limitations mentioned, a spatial comparison showed that traffic emissions are not the main cause 
of the spatial distribution of heavy metals in pavement joints. Instead, we found strong correlations between run-off accumulation and heavy metal pollution, mainly at run-off gathering points. The accumulation of heavy metals at gathering points is supported by an alkaline $\mathrm{pH}$ milieu and adsorption processes on organic material, which makes up a substantial part of pavement joints. Therefore, the material used during the construction of pavements should be carefully considered so as to avoid anthropogenic soil environments that foster heavy metal accumulation (basaltic rock material with highly alkaline milieus). As pavement joints are mainly constructed with the function of water infiltration in sealed areas, the solution and transport of accumulated heavy metals poses a possible risk for the environment outside of urban areas (e.g. river ecosystems and floodplain systems). In addition to the direct risks of accumulated heavy metals (e.g. direct exposure to humans or urban dust emissions), current research needs to pay more attention to this special field of urban soils. We encourage the following topics to be regarded as relevant for further research:

- More attention should be paid to pollution of pavement joints and soils in general as these soils play a major role in urban environments, can react as pollutant accumulative materials and may pose a direct risk to humans.

- More research on urban soil pollution could enable the development of urban geochemical background values for different pollutants, which can promote more effective risk assessments and spatial comparisons - even with pollution indices.

- Different sources of heavy metals, besides traffic and transport in urban areas (e.g. surface run-off), need to be considered to develop effective management strategies of urban soil pollution.

- Run-off and its role must be examined more closely. Further studies about pollution concentration in drainage from pavements, and the infiltration of drainage, are necessary, not only in single areas, but also with a spatial (e.g. geospatial sampling approaches) and temporal (e.g. long-time studies and event-based sampling) resolution.

Data availability. Our research data are available from the following data repository: https://doi.org/10.17632/b3d66r56k8.1 (Weber et al., 2020).

Supplement. The supplement related to this article is available online at: https://doi.org/10.5194/soil-7-15-2021-supplement.

Author contributions. CJW carried out the conceptualisation and selection of the methodology. CJW and AS performed the data curation, investigation and formal analyses. PC carried out the project administration and supervision and provided the resources. The visualisation and writing of the original draft were performed by CJW, with contributions from all co-authors. Writing during the review and editing stage was performed by AS and PC.

Competing interests. The authors declare that they have no conflict of interest.

Acknowledgements. The authors gratefully acknowledge the support from Nina Zitzer during laboratory analyses and ICP-MS measurements.

Review statement. This paper was edited by Jerzy Weber and reviewed by two anonymous referees.

\section{References}

Ad-hoc AG Boden: Bodenkundliche Kartieranleitung, Schweizerbart, Stuttgart, Germany, 2005.

Alloway, B. J.: Heavy Metals in Soils, Springer, Dordrecht, The Netherlands, 2013.

Arnfield, A.J.: Two decades of urban climate research: A review of turbulence, exchanges of energy and water, and the urban heat island, Int. J. Climatol., 23, 1-26, https://doi.org/10.1002/joc.859, 2003.

Atanackovic, N., Dragisic, V., Stojkovic, J., Papic, P., and Zivanovic, V.: Hydrochemical characteristics of mine waters from abandoned mining sites in Serbia and their impact on surface water quality, Environ. Sci. Pollut. R., 20, 7615-7626, https://doi.org/10.1007/s11356-013-1959-4, 2013.

Bąbelewska, A.: The impact of industrial emissions on heavy metal and sulphur contamination level within the area of the projected Jurassic National Park, Prądnik Studies and Reports of the Prof Władysław Szafer Museum, 20, 135-145, 2010.

Bain, D. C., Ritchie, P. F. S., Clark, D. R., and Duthie, D. M. L.: Geochemistry and mineralogy of weathered basalt from Morvern, Scotland, Mineral. Mag., 43, 865-872, 1980.

Bean, E. Z., Hunt, W.-F., and Bidelspach, D. A.: Field survey of permeable pavement surface infiltration rates, J. Irrig. Drain. E., 133, 249-255, https://doi.org/10.1061/(ASCE)07339437(2007)133:3(249), 2007.

Björk, F. and Eriksson, C. A.: Measurement of alkalinity in concrete by a simple procedure, to investigate transport of alkaline material from the concrete slab to a self-levelling screed, Constr. Build. Mater., 16, 535-542, 2002.

Blume, H.-P., Horn, R., and Thiele-Bruhn, S.: Handbuch des Bodenschutzes: Bodenökologie und -belastung; vorbeugende und abwehrende Schutzmaßnahmen, Wiley-VCH, Weinheim, Germany, 2011.

Blume, H.-P., Brümmer, G. W., Fleige, H., Horn, R., Kandeler, E., Kögel-Knabner, I., Kretzschmar, R., Stahr, K., and Wilke, B.M.: Scheffer/Schachtschabel Soil Science, Springer, Berlin and Heidelberg, Germany, 2016. 
Bryan Ellis, J. and Revitt, D. M.: Incidence of heavy metals in street surface sediments: Solubility and grain size studies, Water Air Soil Pollution, 17, 87-100, 1982.

Bundesregierung: Bundes-Bodenschutz- und Altlastenverordnung: BBodSchV, Bundesregierung, Berlin, 1998.

Bund-/Länderarbeitsgemeinschaft Bodenschutz: Hintergrundwerte für anorganische und organische Stoffe in Böden, Bund/Länderarbeitsgemeinschaft Bodenschutz, Magdeburg, Germany, 2003.

Bürgerversammlung Marbach: Entwicklung der Verkehre in Marburg (Traffic development in Marburg), unpublished presentation, Stadt Marburg, Marburg, Germany, 2019.

Burghardt, W.: Zur Gliederung von Stadtböden und ihrer Substrate, Mitteilungen der Deutschen Bodenkundlichen Gesellschaft, 76, 997-1000, 1995.

Burghardt, W., Morel, J. L., and Zhang, G.-L.: Development of the soil research about urban, industrial, traffic, mining and military areas (SUITMA), Soil Sci. Plant Nutr., 61, 3-21, 2015.

Cai, C., Xiong, B., Zhang, Y., Li, X., and Nunes, L. M.: Critical Comparison of Soil Pollution Indices for Assessing Contamination with Toxic Metals, Water Air Soil Pollution, 226, 352, https://doi.org/10.1007/s11270-015-2620-2, 2015.

Chopra, M., Kakuturu, S., Ballok, C., Spence, J., and Wanielista, M.: Effect of rejuvenation methods on the infiltration rates of pervious concrete pavements, J. Hydrol. Eng., 15, 426-433, https://doi.org/10.1061/(ASCE)HE.1943-5584.0000117, 2010.

Christoforidis, A. and Stamatis, N.: Heavy metal contamination in street dust and roadside soil along the major national road in Kavala's region, Greece, Geoderma, 151, 257-263, https://doi.org/10.1016/j.geoderma.2009.04.016, 2009.

Craul, P. J.: Urban soils: Applications and practices, Wiley, New York, USA, 1999.

Defo, C., Yerima, B. P. K., and Bemmo, N.: Investigating soils retention ratios and modelling geochemical factors affecting heavy metals retention in soils in a tropical urban watershed, Environ. Dev. Sustain., 19, 1649-1671, https://doi.org/10.1007/s10668016-9819-2, 2017.

Deutsches Institut für Normung e.V.: Handbuch der Bodenuntersuchung. Terminologie, Verfahrensvorschriften und Datenblätter; physikalische, chemische, biologische Untersuchungsverfahren; gesetzliche Regelwerke, Wiley-VCH, Berlin, Germany, 2000.

Dierkes, C., Holte, A., and Geiger, W. F.: Heavy metal retention within a porous pavement structure, in: Proceedings of the Eighth International Conference on Urban Storm Drainage, 30 August3 September 1999, Sydney, 1955-1962, 1999.

Dierkes, C., Kuhlmann, L., Kandasamy, J., and Angelis, G.: Pollution retention capability and maintenance of permeable pavements, in: Urban drainage 2002: Global solutions for urban drainage, edited by: Strecker, E. W. and Huber, W. C., American Society of Civil Engineers, Reston, VA, USA, 1-13, 2004.

Dierkes, C., Lohmann, M., Becker, M., and Raasch, U.: Pollution retention of different permeable pavements with reservoir structure at high hydraulic loads, in: Proceedings of the 10th International Conference on Urban Drainage, Copenhagen, Denmark, 21 August-26 August 2005, 2005.

Dragovic, S., Mihailovic, N., and Gajic, U.: Heavy metals in soils: Distribution, relationship with soil characteristics and radionuclides and multivariate assessment of contamination sources, Chemosphere, 72, 491-495, https://doi.org/10.1016/j.chemosphere.2008.02.063, 2008.

Drake, J. and Bradford, A.: Assessing the potential for restoration of surface permeability for permeable pavements through maintenance, Water Sci. Technol., 68, 1950-1958, https://doi.org/10.2166/wst.2013.450, 2013.

Drake, J., Bradford, A., and van Seters, T.: Stormwater quality of spring-summer-fall effluent from three partialinfiltration permeable pavement systems and conventional asphalt pavement, J. Environ. Manage., 139, 69-79, https://doi.org/10.1016/j.jenvman.2013.11.056, 2014.

Duong, T. T. T. and Lee, B.-K.: Determining contamination level of heavy metals in road dust from busy traffic areas with different characteristics, J. Environ. Manage., 92, 554-562, https://doi.org/10.1016/j.jenvman.2010.09.010, 2011.

Fach, S. and Geiger, W. F.: Effective pollutant retention capacity of permeable pavements for infiltrated road runoffs determined by laboratory tests, Water Sci. Technol., 51, 37-45, 2005.

FAO: Guidelines for soil description, Food and Agriculture Organization of the United Nations, Rome, Italy, 2006.

Friedrich, K. and Lügger, K.: Hintergrundwerte von Spurenstoffen in hessischen Böden, Hessian Agency of Nature Conservation, Environment and Geology (HLNUG), Wiesbaden, Germany, 2011.

Gałuszka, A., Migaszewski, Z. M., and Zalasiewicz, J.: Assessing the Anthropocene with geochemical methods, Geological Society, London, Special Publications, 395, 221-238, 2014.

Gilbert, J. K. and Clausen, J. C.: Stormwater runoff quality and quantity from asphalt, paver, and crushed stone driveways in Connecticut, Water Res., 40, 826-832, https://doi.org/10.1016/j.watres.2005.12.006, 2006.

Grimmond, C. S. B. and Oke, T. E.: Aerodynamic properties of urban areas derived from analyses of surface form, J. Appl. Meteorol., 38, 1262-1292, 1998.

Gunawardena, J., Ziyath, A. M., Egodawatta, P., Ayoko, G. A., and Goonetilleke, A.: Sources and transport pathways of common heavy metals to urban road surfaces, Ecol. Eng., 77, 98-102, https://doi.org/10.1016/j.ecoleng.2015.01.023, 2015.

Hagler, G. S. W., Tang, W., Freeman, M. J., Heist, D. K., Perry, S. G., and Vette, A. F.: Model evaluation of roadside barrier impact on near-road air pollution, Atmos. Environ., 45, 2522-2530, https://doi.org/10.1016/j.atmosenv.2011.02.030, 2011.

Hakanson, L.: An ecological risk index for aquatic pollution control. a sedimentological approach, Water Res., 14, 975-1001, https://doi.org/10.1016/0043-1354(80)90143-8, 1980.

Herms, U. and Brümmer, G.: Einflussgrößen der Schwermetalllöslichkeit und -bindung in Böden, J. Plant Sci. Soil Sci., 147, 400424, 1984.

Herngren, L., Goonetilleke, A., and Ayoko, G. A.: Analysis of heavy metals in road-deposited sediments, Analytica Chemica Acta, 571, 270-278, https://doi.org/10.1016/j.aca.2006.04.064, 2006.

Hessen Mobil: Verkehrszählung 2015 (Traffic census 2015), available at: https://mobil.hessen.de/\%C3\%BCber-uns/ downloads-formulare/stra\%C3\%9Fenverkehrsz\%C3\% A4hlung-2015, last access: 5 July 2020.

Hessian administration for land management and geoinformation: Airborne laser scanning dataset, Hessian Administration for 
Land Management and Geoinformation, Wiesbaden, Germany, 2019.

Hessisches Statistisches Landesamt: Hessische Gemeindestatistik 2019 (Hessian municipal statistics 2019), Hessisches Statistisches Landesamt (Hessian State Statistical Office), Wiesbaden, Germany, 2019.

IPCC: Global Warming of $1.5^{\circ} \mathrm{C}$. An IPCC Special Report on the impacts of global warming of $1.5^{\circ} \mathrm{C}$ above pre-industrial levels and related global greenhouse gas emission pathways, in the context of strengthening the global response to the threat of climate change, sustainable development, and efforts to eradicate poverty, edited by: Masson-Delmotte, V., Zhai, P., Pörtner, H.-O., Roberts, D., Skea, J., Shukla, P. R., Pirani, A., Moufouma-Okia, W., Péan, C., Pidcock, R., Connors, S., Matthews, J. B. R., Chen, Y., Zhou, X., Gomis, M. I., Lonnoy, E., Maycock, T., Tignor, M., and Waterfield, T., IPCC, Genf, 2018.

IUSS Working Group: World reference base for soil resources 2014, update 2015: International soil classification system for naming soils and creating legends for soil maps, World Soil Resources Reports, FAO, Rome, 203 pp., 2015.

Jung, S. and Masberg, P.: Major- and trace element systematics and isotope geochemistry of cenozoic mafic volcanic rocks from the Vogelsberg (Central Germany): Constraints on the origin of continental alkaline and tholeiitic basalts and their mantle sources, J. Volcanol. Geoth. Res., 86, 151-177, 1998.

Kabata-Pendias, A.: Trace elements of soils and plants, CRC press, Boca Raton, FL, USA, 2011.

Kowalska, J. B., Mazurek, R., Gąsiorek, M., and Zaleski, T.: Pollution indices as useful tools for the comprehensive evaluation of the degree of soil contamination - A review, Environ. Geochem. Hlth, 40, 2395-2420, https://doi.org/10.1007/s10653-018-0106z, 2018.

Lee, S. Z., Chang, L., Yang, H. H., Chen, C. M., and Liu, M. C.: Adsorption characteristics of lead onto soils, J. Hazard. Mater., 63, 37-49. https://doi.org/10.1016/S0304-3894(98)00203-9, 1998.

Lehmann, A. and Stahr, K.: Nature and significance of anthropogenic urban soils, J. Soils Sediment., 7, 247-260, https://doi.org/10.1065/jss2007.06.235, 2007.

Li, Z., Ma, Z., van der Kuijp, T. J., Yuan, Z., and Huang, L.: A review of soil heavy metal pollution from mines in China: Pollution and health risk assessment, Sci. Total Environ., 468/469, 843-853, https://doi.org/10.1016/j.scitotenv.2013.08.090, 2014.

Logiewa, A., Miazgowicz, A., Krennhuber, K., and Lanzerstorfer, C.: Variation in the concentration of metals in road dust size fractions between $2 \mathrm{~m}$ and $2 \mathrm{~mm}$ : Results from three metallurgical centres in Poland, Arch. Environ. Con. Tox., 78, 46-59, https://doi.org/10.1007/s00244-019-00686-x, 2020.

Lu, S. G. and Bai, S. Q.: Contamination and potential mobility assessment of heavy metals in urban soils of Hangzhou, China: relationship with different land uses, Environ. Earth-Sci., 60, 1481-1490, https://doi.org/10.1007/s12665-009-0283-2, 2010.

Luo, X.-S., Yu, S., Zhu, Y.-G., and Li, X.-D.: Trace metal contamination in urban soils of China, Sci. Total Environ., 421/422, 1730, https://doi.org/10.1016/j.scitotenv.2011.04.020, 2012.

Mahanta, M. J. and Bhattacharyya, K. G.: Total concentrations, fractionation and mobility of heavy metals in soils of urban area of Guwahati, India, Environ. Monit. Assess., 173, 221-240, https://doi.org/10.1007/s10661-010-1383-x, 2011.
Manta, D. S., Angelone, M., Bellanca, A., Neri, R., and Sprovieri, M.: Heavy metals in urban soils: a case study from the city of Palermo (Sicily), Italy, Sci. Total Environ., 300, 229-243, https://doi.org/10.1016/S0048-9697(02)00273-5, 2002.

McLaren, R. G., Williams, J. G., and Swift, R. S.: The adsorption of copper by soil samples from Scotland at low equilibrium solution concentrations, Geoderma, 31, 97-106, https://doi.org/10.1016/0016-7061(83)90001-0, 1983.

Miller, J. R.: The role of fluvial geomorphic processes in the dispersal of heavy metals from mine sites, J. Geochem. Explor., 58, 101-118, 1997.

Munzi, S., Correia, O., Silva, P., Lopes, N., Freitas, C., Branquinho, C., and Pinho, P.: Lichens as ecological indicators in urban areas: beyond the effects of pollutants, J. Appl. Ecol., 51, 1750-1757, https://doi.org/10.1111/1365-2664.12304, 2014.

R Core Team: R: A language and environment for statistical computing, R Foundation for Statistical Computing, Vienna, Austria, available at: https://www.R-project.org/, last access: 3 February 2019.

Räsänen, V. and Penttala, V.: The $\mathrm{pH}$ measurement of concrete and smoothing mortar using a concrete powder suspension, Cement Concrete Res., 34, 813-820, https://doi.org/10.1016/j.cemconres.2003.09.017, 2004.

Rudnick, R. L. and Gao, S.: Composition of the continental crust, treatise on geochemistry, Treatise on Geochemistry, 3, 1-64, 2003.

Sakson, G., Brzezinska, A., and Zawilski, M.: Emission of heavy metals from an urban catchment into receiving water and possibility of its limitation on the example of Lodz city, Environ. Monit. Assess., 190, 281, https://doi.org/10.1007/s10661-0186648-9, 2018.

Sansalone, J. J., Koran, J. M., Smithson, J. A., and Buchberger, S. G.: Physical characteristics of urban roadway solids transported during rain events, J. Environ. Eng., 124, 427-440, https://doi.org/10.1061/(ASCE)0733-9372(1998)124:5(427), 1998.

Schad, P.: Technosols in the World Reference Base for Soil Resources - history and definitions, Soil Sci. Plant Nutr., 64, 138144, https://doi.org/10.1080/00380768.2018.1432973, 2018.

Seaward, M. R. D.: Lower plants and the urban landscape, Urban Ecol., 4, 217-225, 1979.

Sorme, L. and Lagerkvist, R.: Sources of heavy metals in urban wastewater in Stockholm, Sci. Total Environ., 298, 131-145, https://doi.org/10.1016/S0048-9697(02)00197-3, 2002.

Strode, S., Jaeglé, L., and Selin, N. E.: Impact of mercury emissions from historic gold and silver mining: Global modeling, Atmos. Environ., 43, 2012-2017, https://doi.org/10.1016/j.atmosenv.2009.01.006, 2009.

Tetoldi, D., Chebbo, G., Pierlot, D., Kovacs, Y., and Gromaire, M.-C.: Impact of runoff infiltration on contaminant accumulation and transport in the soil/filter media of Sustainable Urban Drainage Systems: A literature review, Sci. Total Environ., 569, 904-926, 2016.

Tedoldi, D., Chebbo, G., Pierlot, D., Branchu, P., Kovacs, Y., and Gromaire, M.-C.: Spatial distribution of heavy metals in the surface soil of source-control stormwater infiltration devices - Inter-site comparison, Sci. Total Environ., 579, 881-892, https://doi.org/10.1016/j.scitotenv.2016.10.226, 2017. 
Thomas, R.: A beginner's guide to ICP-MS - Part VII: Mass separation devices - Double-focusing magnetic-sector technology, Spectroscopy, 16, 22-27, 2001.

United Nations, Department of Economic and Social Affairs: Population Division (2019), World Urbanization Prospects, The 2018 Revision (ST/ESA/SER.A/420), United Nations, New York, USA, 2019.

Vardoulakis, S., Fisher, B. E. A., Pericleous, K., and GonzalezFlesca, N.: Modelling air quality in street canyons: a review, Atmos. Environ., 37, 155-182, https://doi.org/10.1016/S13522310(02)00857-9, 2003.

Voica, C., Dehelean, A., Iordache, A., and Geana, I.: Method validation for determination of metals in soils by ICP-MS, Rom. Rep. Phys., 64, 221-231, 2012.

Wang, X., Wang, X., Sun, X., Berlyn, G. P., and Rehim, A.: Effect of pavement and water deficit on biomass allocation and whole-tree transpiration in two contrasting urban tree species, Urban Ecosyst., 23, 893-904, https://doi.org/10.1007/s11252020-00953-z, 2020.

Weber, C. J., Santowski, A., and Chifflard, P.: Spatial variability of heavy metal concentration in urban pavement joints - A case study, Mendeley Data v1, https://doi.org/10.17632/b3d66r56k8.1, 2020.

Wei, T. and Simko, V.: R package "corrplot": Visualization of a Correlation Matrix (Version 0.84), available at: https://github.com/ taiyun/corrplot (last access: 3 February 2019), 2017.
Weihrauch, C.: Phosphor-Dynamiken in Böden, Springer Spektrum, Wiesbaden, 369 pp., https://doi.org/10.1007/978-3-658-22348-9, 2018.

Wessolek, G., Kluge, B., Nehlis, T., and Kocher, B.: Aspekte zum Wasserhaushalt und Stofftransport urbaner Flächen, Korrespondenz Wasserwirtschaft, 4, 1-12, 2009.

Yan, X., Gao, D., Zhang, F., Zeng, C., Xiang, W., and Zhang, M.: Relationships between heavy metal concentrations in roadside topsoil and distance to road edge based on field observations in the Qinghai-Tibet Plateau, China, Int. J. Env. Res. Pub. He., 10, 762-775, https://doi.org/10.3390/ijerph10030762, 2013.

Zhang, K., Yong, F., McCarthy, D. T., and Deletic, A.: Predicting long term removal of heavy metals from porous pavements for stormwater treatment, Water Res., 142, 236-245, https://doi.org/10.1016/j.watres.2018.05.038, 2018.

Zhang, R., Zhang, Y., Liu, L., Wang, Y., Song, Z., Wang, Z., Liu, C., Li, Y., Meng, W., Zhou, Y., Sun, D., and Qi, F.: Occurrence and risk assessment of heavy metals in an urban river supplied by reclaimed wastewater, Water Environ. Res., 92, 1888-1898, https://doi.org/10.1002/wer.1341, 2020.

Zimmermann-Janschitz, S.: Statistik in der Geographie: Eine Exkursion durch die deskriptive Statistik, Springer Spektrum, Berlin, Germany, 2014. 